more categories of unilateral error, codification might be desirable. Experience has already been had with this solution in Germany. ${ }^{4 x}$

Although Professor Williston maintains that "a doctrine which permits the rescission of a contract on account of unilateral mistake approaches nearly to a contradiction of the objective theory of mutual assent in the formation of contracts to which the modern law seems generally to have tended," ${ }_{42}$ he concedes the workability of a "subjective" theory of mistake when coupled with an estoppel or reliance interest theory. 43 The approach to unilateral mistake suggested here would detract nothing from the many advantages of the "objective" theory but would alleviate an occasional harshness. The reasons of policy ${ }^{44}$ which dictate relief for mutual mistake apply as well to unilateral error. It seems more important that the law be determined by social policy and notions of fairness than that it be symmetrically "objective" or "subjective."

\title{
HEALTH INSPECTION OF PRTVATE DWELLING WITHOUT SEARCH WARRANT
}

In answer to a complaint that the halls of a private dwelling were littered with trash and garbage, a uniformed health inspector of the District of Columbia, accompanied by a police officer, asked permission to enter the dwelling and investigate. The owner refused to unlock her door and admit him, insisting that she was under no obligation to do so since neither the inspector nor the police officer had a search warrant. As a result of this refusal, the owner was convicted of a violation of the health law. ${ }^{x}$ The Supreme Court affirmed the reversal of the

4I German Civil Code $\S$ IIg (2), states that unilateral impalpable mistake entitles the mistaken party to rescission. Under Section $\mathbf{1 2 2}$ the nonmistaken party may receive damages for injuries suffered because of reliance upon the validity of the contract.

${ }^{42} 5$ Williston, Contracts $\S$ I579 (rev. ed. $x_{937}$ ).

43 Ibid., at $\$ 1536$ n. 4 .

44 Note 3 supra. While it is often said that relief is not given for unilateral mistake because the nonmistaken party relied on the existence of a binding obligation, this is true as well of the party resisting relief in a case of mutual mistake.

I "[I]t shall be the duty of every person occupying any premises, or any part of any premises, in the District of Columbia, or, if such premises be not occupied, of the owner thereof, to keep such premises or part ... clean and wholesome. If upon inspection by the Health Officer or an inspector of the Health Department, it be determined that any such part thereof, or any building, yard ... is not in such condition as herein required, the occupant or occupants of such premises or part, or the owner thereof ... shall be notified and required to place the same in a clean and wholesome condition; and in case any person shall fail or neglect to place such premises or part in such condition within the time allowed by said notice, he shall be liable to the penalties hereinafter provided. $\S 2$.

"That any person violating or aiding or abetting in violating, any of the provisions of these regulations, or interfering with or preventing any inspection authorized thereby, shall be deemed guilty of a misdemeanor, and shall, upon conviction ... be punished by a fine of not less than $\$ 5.00$ nor more than $\$ 45.00$. $\S$ I 2." District of Columbia v. Little, 339 U.S. I, 4 n. 2 (1950). 
trial court's verdict. ${ }^{2}$ However, the decision was not based on the opinion of the Court of Appeals for the District of Columbia, ${ }^{3}$ which held that the owner was protected by the Fourth Amendment 4 and that the inspection of a private dwelling without a warrant was an unreasonable exercise of the police power. Instead, the Court chose to avoid the constitutional question and held that there had been no interference with the health inspector within the meaning of the inspection statute.

The question of whether the owner's acts amounted to interference within the meaning of the statute does not appear to have been argued at any stage of the litigation. ${ }^{5}$ The lower courts based their decisions solely on the constitutional grounds. The District of Columbia statute provided a penalty for anyone "interfering with or preventing any inspection." The dissenting justices, Burton and Reed, together with the lower court judges, apparently felt that since the defendant refused to unlock her door, there had been an effective interference with the inspection procedure. Nevertheless, the majority, focussing upon the word "interfere" and ignoring the word "prevent" held that the statute was not meant to extend to actions of this type.7 This distortion was caused by the

$=$ District of Columbia v. Little, 339 U.S. I (r950). Justices Burton and Reed dissented. They believed that the statute had been violated, but that health inspection did not require a warrant.

3 District of Columbia v. Little, $x_{7} 8$ F. $2 \mathrm{~d}$ I3 $_{3}$ (1949). The Municipal Court opinion is in $62 \mathrm{~A} .2 \mathrm{~d} 874$ (1948). Judge Holtzoff of the court of appeals dissented. He maintained that the Fourth Amendment only required a warrant in the case of a search for evidence or for other criminal matters. Since the inspection in the instant case was not related to the dangers likely in the issuance of general warrants with their exploratory searches, the dissent expressed the opinion that the Fourth Amendment was not applicable. It was also stated that the warrant requirement would result in judicial supervision of an administrative job, an undesirable result. The cases cited in the dissent, however, do not involve the invasion of a private dwelling, but are concerned with searches of hotels, automobiles and other instances of federal seizure which have traditionally been excluded from the amendment's provisions.

4 "The right of the people to be secure in their persons, houses, papers, and effects, shall not be violated, and no warrants shall issue, but upon probable cause, supported by oath or affirmation, and particularly describing the place to be searched, and the person or things to be seized."

5 District of Columbia v. Little, 339 U.S. I, $4 \mathrm{n}$. I (I950).

${ }^{6}$ Note I supra.

7 The Court's interpretation of the statute, in relation to the facts of this particular case, does not appear to be reasonable. Short of an actual physical assault on the inspector, it is difficult to imagine a more effective means of preventing the inspection than locking the door. If Section I2 of the statute was not drafted with such an obvious means as this in view, its whole purpose is nugatory. In United States v. McDonald, 8 Biss. 439,448 (C.C.A. Wis., I879) the court construed a statute which provided a penalty for anyone who "knowingly and willfully obstructs, resists or opposes any officer of the United States in serving or attempting to serve ... process or warrant." In interpreting this section the court said: "The statute, however, does not limit the offense to resistance alone, it includes also willful acts of obstruction or opposition; and to obstruct is to interpose obstacles or impediments, to hinder, impede or in any manner interrupt or prevent, and this term does not necessarily imply the 
Court's determination to avoid several important and controversial questions. To accomplish it the Court took refuge in a long established policy by which constitutional issues are ignored if a valid alternative point of statutory construction or general law is presented. ${ }^{8}$

In avoiding the determination of these constitutional problems, the Court emasculated the District of Columbia health inspection statute. This decision prevents a health inspector from entering a private dwelling even with a warrant, as long as the door is locked, because such conduct is not "interference" within the meaning of the statute. It is ironical that although certiorari was granted because "the case raises important questions concerning legal provisions for protecting the health of the people by special and periodic inspection and elimination of potential sources of disease," 9 the decision established a simple loophole for those who may wish to resist inspection. The Court also refused an excellent opportunity to establish an important precedent on the three major points embodied in the opinion of the court of appeals: the scope of health inspection; the constitutional requirements for the entry of a private dwelling; and the civil liberties protection needed to safeguard citizens from the arbitrary intrusion of governmental officers.

District of Columbia v. Little, which clearly presented these three points for decision, represents a departure from the previous litigation arising under the Fourth Amendment.10 There was no attempt to apprehend a criminal, make an arrest, or seize evidence of a crime. The circumstances involved merely a routine inspection, the kind which any large city undertakes every week. The

employment of direct force, or the exercise of direct means. It included any passive, indirect or circuitous impediments to the service or execution of process; such as hindering or preventing an officer by not opening a door." This interpretation of "obstruct, resist and oppose" is contrary to the Supreme Court's partial reliance on the lack of force or threatened force in the Little case by which they justify a holding of noninterference. It also equates "hindering" with "preventing," although the Supreme Court sought to distinguish the District of Columbia statute because it did not use the words "hindering" or "refusing to permit any lawful inspection."

${ }^{8}$ Siler v. Louisville \& Nashville R. Co., 2I3 U.S. I75 (Igog); Light v. United States, 220 U.S. 523 (IgII); Ashwander v. Tennessee Valley Authority, 297 U.S. 288, 347 (I936). However, constitutional questions can not be avoided unless it is "fairly possible" to decide the case on the statutory level. Rescue Army v. Municipal Court of Los Angeles, 33I U.S. 549, 569 (1947). In the Rescue case, which the Court cites to support this rule, Justices Murphy and Douglas dissented for the express reason that the constitutional issues were clearly raised and the time was "ripe for this Court to supply the definitive judicial answers." Ibid., at 585 .

- District of Columbia v. Little, 339 U.S. I, 2-3 (I950).

so See Harris v. United States, 33I U.S. I45, I75-8I (I947), where in his dissent, Justice Frankfurter compiled a list of the twenty-six Supreme Court cases arising from $19{ }^{2} 4$ to $x_{93} 8$ in which the Fourth Amendment was involved. Each of these cases was concerned in some manner with a crime, or with the payment of a penalty or a forfeiture. The Supreme Court's interpretation of the Fourth Amendment has in fact been criticized as a sentimental concession to criminals and a positive obstruction to criminal justice. This view is discussed in Waite, Reasonable Search and Research, 86 U. of Pa. L. Rev. 623 (I938). 
health departments of such large cities as Los Angeles ${ }^{\mathrm{rI}}$ and Chicago ${ }^{\mathrm{r} 2}$ operate in the same manner in answering complaints. Their statutes also impose fines upon those who interfere with the inspections and in general are similar to the District of Columbia statute.

Officials ${ }^{\mathrm{r}_{3}}$ of the health and law departments of the city of Chicago say that complaints of the Little type are not unusual. In answering them, the Chicago health inspectors state the nature of the complaint, show their credentials and ask permission to enter. Usually no objection is made. However, the officials report that from time to time an individual will refuse to admit the inspector. When this occurs the law department initiates a prosecution under the authority of the health statute. It was reported that these interferences are the exception, and to the knowledge of these officials, the defense of constitutional immunity has never been raised.14

It is surprising that there had been no decision on the constitutionality of health inspection of a private dwelling without a warrant. In fact, the Little case was one of the few decisions in which the application of the Fourth Amendment

II "No person shall refuse to permit or allow the Health Officer or any of his deputies, agents or inspectors of the Department to enter, inspect, or examine or interfere with or hinder such Health Officer or his deputies, agents, or any inspector of the Department in the inspection or examination of any portion of any building, premises, lot, vehicle, steamboat, boat, vessel, train, bus, street car, food or food products, goods, wares, equipment, things, apparatus, instruments, persons, animals or registers, or the examination or inspection of the doing of any and all things or acts necessary and mandatory for him (or them) to do for the purpose of enforcing all the provisions of this Chapter, the rules and regulations of the Department, or any health law of the State." Los Angeles Rev. Code (I946) \& 3 I.I8.

"The occupant or the owner ... managing any dwelling ... shall thoroughly clean all the rooms, passages, floors, windows, doors, walls, ceilings, water closets, privies, cesspools and drains of the building ... which he ... manages or occupies, to the satisfaction of the Health Officer, as often as shall be required." Ibid., at $\$ 32.00$.

"It shall be unlawful for any person to violate any provisions or to fail to comply with any of the requirements of this Code. Any person violating any provisions or failing to comply with any of the mandatory requirements of this Code, shall be guilty of a misdemeanor. Any person convicted of a misdemeanor under the provisions of this Code, unless provision is otherwise herein made, shall be punishable by a fine of not more than $\$ 500.00$ or by imprisonment in the City Jail for a period of not more than sis months or by both such fine and imprisonment." Ibid., at $\S \mathrm{II} . \infty(\mathrm{m})$.

I2 "The commissioner of buildings, president of the board of health, fire commissioner, commissioner of public works, commissioner of streets and electricity, commissioner of police, or any of them and their respective assistants, shall have the right to enter any building, or premises, and any and all parts thereof, at any reasonable time, and at any time when occupied - by the public in order to examine such building or premises to judge of the condition of the same and to discharge their respective duties, and it shall be unlawful for any person to interfere with them in the performance of their duties." Chicago Rev. Code (Igog) \& $39 \cdot 3$.

"Any person violating or resisting or opposing the enforcement of any of the provisions of this chapter, where no other penalty is provided, shall be fined not more than two hundred dollars for each offense ...." Ibid., at $\$ 39.9$.

${ }_{13}$ The information concerning the Chicago Health inspection procedure was gathered from extended conversations with officials in both the health and law departments of the city.

${ }^{14} \mathrm{~A}$ thorough examination of cases and other sources in Illinois has failed to disclose any report or opinion in which the matter is discussed. 
to a private dwelling under noncriminal circumstances was argued. Perhaps the infrequency with which health inspectors have met opposition accounts for the lack of direct authority on these issues. The District of Columbia has no provision for the granting of a warrant for health inspection. Both counsel for the District of Columbia and the dissenting opinion in the court of appeals emphasized that this fact should be considered in weighing the social policies of domestic privacy against the necessity for proper health protection. The majority opinion in the court of appeals sympathized with this position, but thought that the proper remedy should be supplied by the legislature.

If the Litlle case had been decided on the grounds that a health inspector needed a warrant to enter a private dwelling, the decision could have had farreaching importance by applying it to state and municipal health laws through the due process clause of the Fourteenth Amendment. The Supreme Court has consistently held that the first eight amendments of the Constitution are not directly applicable to the states. ${ }^{25}$ Nevertheless, the states are inhibited by the Fourteenth Amendment from encroaching on those rights of the first eight amendments which are "implicit in the concept of ordered liberty." 16

The clearest expression of the concept "ordered liberty" as applied to the Fourth Amendment is contained in the recent case of Wolf ข. Colorado. ${ }^{17}$ In the Wolf case the Supreme Court was concerned with the applicability of the due process clause of the Fourteenth Amendment to a state criminal trial. One question in the case was whether state officers, acting without a warrant, could search a private office and seize business records without violating the Fourth Amendment. The Court held that the search was unconstitutional. The justices unanimously agreed that the right to be secure in one's home from the arbitrary entry of the police was implicit in the concept "ordered liberty,",8 and therefore enforceable against the states through the due process clause.

If the Little case had required health inspectors to obtain warrants to enter private dwellings when the owner or occupant objected, it might have caused a revision of the health laws and practices of many large cities. This is a strong possibility in view of the Wolf dictum that the right of privacy is enforceable against the states because it is of the essence of "ordered liberty."

If the Supreme Court had adopted the court of appeals opinion, the Little case could also have given further definition to the scope of health inspection. Municipal inspection in the interests of the public health has long been sanc-

xs Barron v. Baltimore, 7 Pet. (U.S.) 242 ( 1833 ); Adamson v. California, 332 U.S. 46 (I947); Twining v. New Jersey, 2Ir U.S. 78 (1908).

${ }^{16}$ Palko v. Connecticut, 302 U.S. 3r9, 325 (r937).

${ }^{17} 338$ U.S. 25 (1949).

${ }^{18}$ As Justice Black stated in his concurring opinion, "A state officer's knock at the door ... as a prelude to a search, without authority of law, may be as our experience shows, just as ominous to 'ordered liberty' as though the knock were made by a federal officer." Ibid., at 40. 
tioned as a valid exercise of the police power, ${ }^{x 9}$ but the inspection of private dwellings has only been permitted where it has been necessary to abate a public nuisance or where the general health of the community has been endangered by the failure to observe proper sanitary measures. ${ }^{20}$ As the majority opinion of the court of appeals in the Little case stated, "If an acute emergency occurs precluding reference to a court or magistrate, public officials must take such steps as are necessary to protect the public." ${ }^{22}$ The court emphasized, however, that "absent such emergency, health laws are enforced by the police power and are subject to the same constitutional limitations as are other police powers." ${ }^{22}$ Since inspections are a form of search, ${ }^{23}$ they are subject to the prohibitions of the Fourth Amendment. In the absence of these special conditions, however, there has been a uniform prohibition against any kind of search of a private

I9 Keiper v. City of Louisville, I52 Ky. 69I, I54 S.W. I8 (IgI3); Hubbell v. Higgins, I48 Iowa 36, I26 N.W. 914 (I9I0). In the Hubbell case the court said: "The power of the legislature to provide for inspection of premises in the interests of public safety and the public health is so well established that we will not enter upon a discussion of it." Ibid., at 46 and 9 I8.

${ }_{20}$ Text writers concur with the view that a private dwelling may not be entered without a warrant. Freund says, "The constitutional aspect of inspection is, however, different where it is extended to interior arrangements of private houses, or personal property kept therein in private custody. It appears that health authorities often claim the right to enter private houses to inspect sanitary arrangements, in some cases by express legal authority. ... This power does not seem to have been affirmed or denied by judicial decision; but on principle it would seem that administrative officers cannot be vested with general power to enter private premises at any time, except to abate actually existing public nuisances, and that every such inspection against the will of the owner should be based on judicial compliance with the constitutional requirements with regard to searches." Freund, Police Power 42-43 (I904).

Worthington advises that "[i]f right of entry to premises for the purpose of inspection is refused, a warrant may be issued by the board or by a magistrate, as the statute provides, directing the sheriff or constable, taking such force as may be necessary, and under the direction of the sanitary authorities, to effect an entry and accomplish the purpose for which entry was required." Parker and Worthington, Public Health and Safety I62 (I892).

${ }^{2 x}$ District of Columbia v. Little, I78 F. 2d I3, 2I (I949).

22 Ibid.

${ }^{23}$ In the Little case the court of appeals said that the distinction between search and inspection 'has no basis in semantics, in constitutional history, or in reason. 'Inspect' means to look at, and 'search' means to look for. To say that the people, in requiring adoption of the Fourth Amendment, meant to restrict invasion of their homes if government officials were looking for something, but not to restrict it if the officials were merely looking, is to ascribe to the electorate of that day and to the several legislatures and the Congress a degree of irrationality not otherwise observable in their dealings with potential tyranny." Ibid., at I8.

Not all searches and seizures are prohibited by the Fourth Amendment, but only those which are unreasonable. Boyd v. United States, II6 U.S. 6I6 (I886). The Court indicated in Go-Bart Importing Co. v. United States, 282 U.S. 344, 357 (I930), that "[ $t$ ] for the determination of reasonableness. Each case is to be decided on its own facts and circumstances." See also In re Ginsburg, r47 F. 2d 749 (C.A. 2d, r945). One criterion of reasonableness is the obtaining of a warrant, as the amendment itself indicates. A warrant may be issued only if the party seeking it has an interest in the property to be seized, either by possession or by the right to ownership, or a valid exercise of police power requires that the property be taken. Agnello v. United States, 269 U.S. 20 (I925). See also Johnson v. United States, 333 U.S. Io (r947); Pearson v. United States, I50 F. 2 d 219 (C.A. Ioth, 1945); Byars v. United States 273 U.S. 28 (I927). 
dwelling unless a valid warrant has been issued upon probable cause. ${ }^{24}$ In Agnello v. United States it was said that "[t]he search of a private dwelling without a warrant is in itself unreasonable and abhorrent to our laws." 25 It would appear that a statute requiring inspection of every private residence for specific purposes would be unconstitutional. ${ }^{26}$ The courts seem to feel that the formality attending the issuance of a warrant acts as a psychological restraint upon officers, impressing upon them that the courts are ever watchful of their conduct.

An adjunct to the protection of the right of privacy which the court of appeals upheld in the Little case was a recognition that unauthorized and unregulated searches by government officers might in the future become instruments of political oppression. Justice Black raised the issue in his concurring opinion in the Wolf case. In their dissents in Davis v. United States ${ }^{27}$ and in Zap v. United States ${ }^{28}$ Justices Frankfurter, Murphy and Rutledge vigorously protested that the right to regulate and inspect does not justify a search without a warrant. Their opinions indicate an awareness of the problem of modern governmenttrying to regulate large cities and vast economic enterprises. Inspection is certainly a logical means with which to protect the public interest. However, as it was stressed by the court of appeals in the Little case, "If private homes are opened to the intrusion of government enforcement officials, at the wish of those officials, without the intervening mind and hand of a magistrate, one prop of the structure of our system is gone and an outstanding characteristic of another form of government will have been substituted." ${ }^{29}$ It may be difficult to

24 Agnello v. United States, 269 U.S. 20 (r925); Gouled v. United States, 255 U.S. 298 (I92I); Amos v. United States, 255 U.S. $3^{\text {I3 }}$ (I92I); Nueslein v. District of Columbia, II5 F. 2d 690 (App. D.C., I940); Boyd v. United States, II6 U.S. 6 I6 (I886). In the Agnello case the Court remarked that "[w]hile the question has never been directly decided by this court, it has always been assumed that one's house cannot lawfully be searched without a search warrant, except as an incident to a lawful arrest therein." 269 U.S. 20, 32 (I925). Evidently the force of the Boyd case and the impact of Entick v. Carrington, 19 How. St. Tr. Iozg (1765), erased any notion that a private dwelling could be searched without a warrant. In the Little case the court of appeals extended this general belief to the peculiar facts of the complaint made to the health officials, one part of which alleged that the occupants of the house "fail[ed] to avail themselves of the toilet facilities." The court observed that "[i]t may be that the boundary of the curtilage is no longer the outpost of man's domestic independence. It may be that a transom is debatable access. But even if the front door of the house is no longer protected by the Constitution, surely it had been thought until now that the bathroom door is." I78 F. 2d I3, I8 (r949).

${ }^{25}$ Agnello v. United States, 269 U.S. 20, at 32 (I925).

${ }^{26}$ In Williams v. State, 100 Ga. 5 II, 520, 28 S.E. 624,627 (I897), the court said, "We believe the framers of the constitution of the United States and of this and other states merely sought to provide against any attempt, by legislation or otherwise, to authorize, justify, or declare lawful, any unreasonable search or seizure. This wise restriction was intended to operate upon legislative bodies, so as to render ineffectual any effort to legalize by statute what the people expressly stipulated could in no event be made lawful."

$$
{ }^{27} 328 \text { U.S. } 582 \text { (1946). } \quad{ }^{28} 328 \text { U.S. } 624 \text { (I946). }
$$

${ }^{29}$ District of Columbia v. Little, $x_{7} 8$ F. $2 \mathrm{~d} \mathrm{I}_{3}$, 16 (r949). 
visualize a threat to liberty in the action of a uniformed health inspector answering a routine complaint. Yet in an era when politically controlled officials have grown powerful through an ever increasing series of minor infractions of civil liberties, it would seem prudent to invoke the full force of the constitutional guarantees at every opportunity. ${ }^{30}$

\section{DIVIDEND CREDITS FOR NONCUMULATIVE PREFERRED STOCK}

In addition to seniority in the distribution of corporate earnings, the cumulative preferred shareholder receives a credit for dividend arrearages accruing when earnings are not sufficient to authorize distributions. Yet in some circumstances it may be undesirable to place the potential burden of such arrearages upon the corporation. Upon reorganization or at the commencement of ventures in which initial years of losses or low profits are anticipated, noncumulative preferred may be a sounder issue. Such stock issues pose a fundamental problem: do the noncumulative preferred shareholders receive a dividend credit for those years when profits are legally adequate to permit some distribution but the directors omit any declaration?

The United States Supreme Court rejected such a dividend credit for noncumulative preferred stock in Wabash Railway Co. v. Barclay. ${ }^{3}$ Speaking through Justice Holmes it asserted:

When a man buys stock instead of bonds he takes a greater risk in the business. No one suggests that he has a right to dividends if there are no net earnings. But the investment presupposes that the business is to go on, and therefore even if there are net earnings, the holder of stock, preferred as well as common, is entitled to have a dividend declared only out of such part of them as can be applied to dividends consistently with a wise administration of a going concern. When ... the dividends in each fiscal year were declared to be noncumulative and no net income could be so applied within the fiscal year referred to in the certificate the right for that year was gone. If the right is extended further upon some conception of policy, it is enlarged beyond the meaning of the contract and the common and reasonable understanding of men.

These arguments, in the context of the apparently plain meaning of "noncumulative" as against "cumulative," have prevailed in all jurisdictions except New Jersey, ${ }^{3}$ The New Jersey position, first expressed in the Cast Iron Pipe cases, 4 is based upon the belief that in the absence of a dividend credit there is

${ }^{30}$ See DeVoto, Due Notice to the FBI, Harper's Magazine (Oct., 1949) at 65.

× 280 U.S. $x 97$ ( 1930 ).

2280 U.S. 197,203 (1930).

3 But writers have advocated various forms of the dividend credit. See Frey, The Distribution of Corporate Dividends, 89 U. of Pa. L. Rev. 735, 750 et seq. (1941); Berle, Noncumulative Preferred Stock, 23 Col. L. Rev. 358 (I923). Frey asserts that most of the writers have approved the dividend credit. $89 \mathrm{O}$. of Pa. L. Rev. 735, 753 (I94I).

1 Bassett v. United States Cast Iron Pipe and Foundry Co., 74 N.J. Eq. 668, 7o Atl. 929 (Ig08), aff'd 75 N.J. Eq. 539, 73 Atl. 514 (I909). (A bill to enjoin the corporation from paying 